\title{
People
}

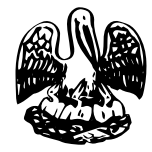

Women in the Family

\begin{tabular}{ll}
\hline $\begin{array}{l}\text { "Peachy" Johnson } \\
\text { James }\end{array}$ & $\begin{array}{l}\text { (1909-1984), Alma, mother of the } \\
\text { Peachy Gang }\end{array}$ \\
\hline Cynthia Winesbury & Peachy's eldest daughter, mother of three
\end{tabular}

Katie Williams Peachy's third daughter, mother of five

Roseana Maurice Peachy's fourth daughter, mother of four

Audrey Brown Peachy's youngest daughter, mother of four

Roz King Katie's oldest daughter

Nell Rosebud Katie's second daughter

Janice Tambrella Cynthia's daughter

Melanie Bienemy Audrey's third daughter

Connie Tipado Peachy's granddaughter (Sherman's

daughter) who lives in Dallas

Robin James

Peachy's granddaughter (Sherman's

daughter) who lives in Violet, La. 


\section{Men in the Family}

\section{Gray Eye (Leroy Sr.) Katie's husband \\ Williams}

Buffy (Gregory)

James

Potchie Smith

Earl Rosebud

Turb (Leroy Jr.)

Williams
Peachy's grandson (Raymond's son) who stayed during the storm

Peachy's grandnephew (Davis's grandson)

Mr T (Terrance) Maurice second son of Roseana, local party DJ

\section{Parish Notables}

Pastor Raymond Smith pastor of First Baptist Church in Verret

Junior Rodriguez

parish president (2004-2008), Isleño

descent, family friend and neighbor in Verret

\section{Outside the Parish}

Martha Ward, Ph.D.

anthropologist and professor at University of New Orleans

Zarus Watson, Ph.D. mental health counseling professor at University of New Orleans

Lolis Elie journalist and filmmaker based in New Orleans 
The Johnson-Fernandez Family

(Simplified)

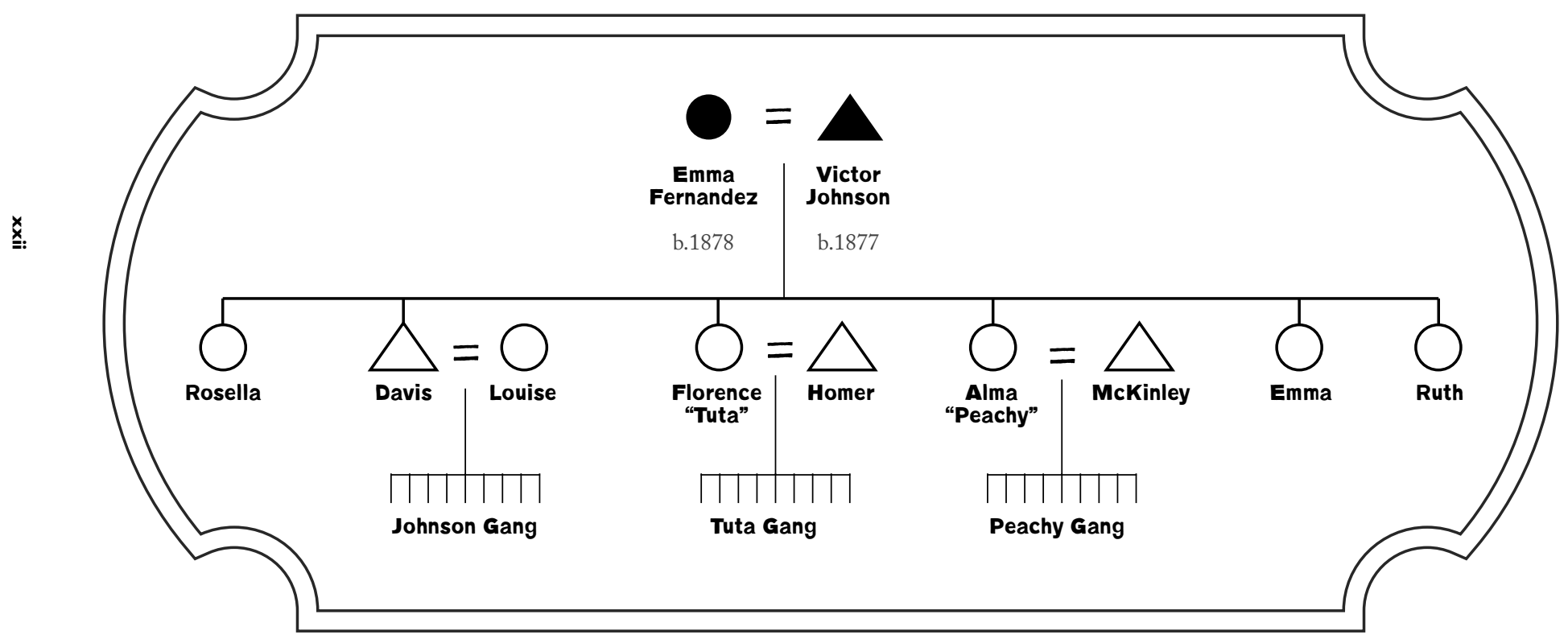




\section{The Peachy Gang}

(Simplified)

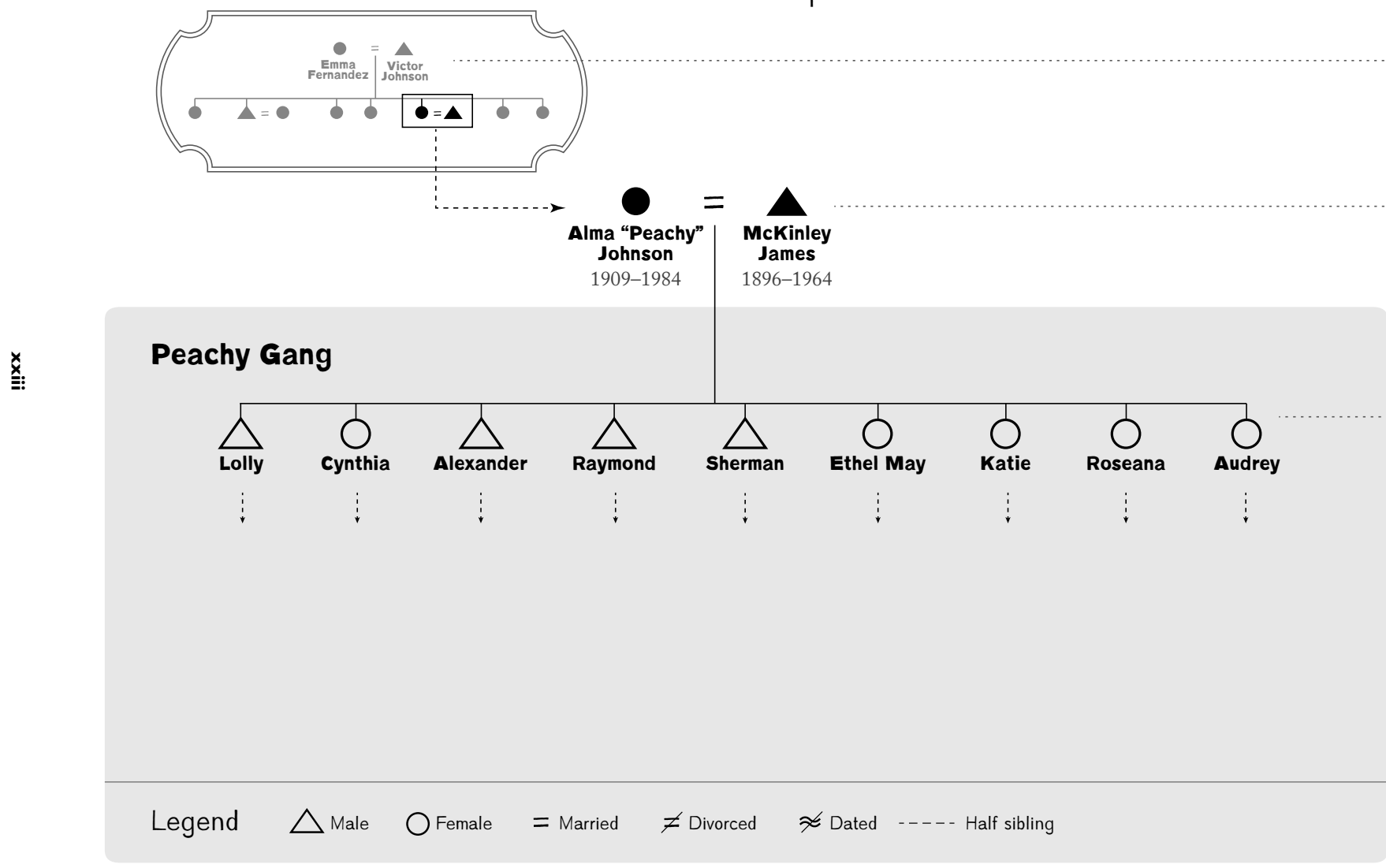

Generation 1 


\section{Lolly's Branch}

(Simplified)

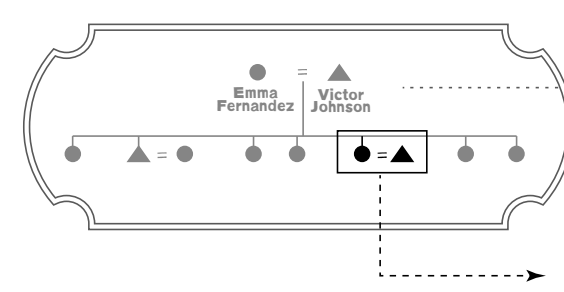

Generation 1

Alma "Peachy" McKinley

Johnson James

1909-1984

1896-1964

\section{Peachy Gang}

$\stackrel{x}{x}$

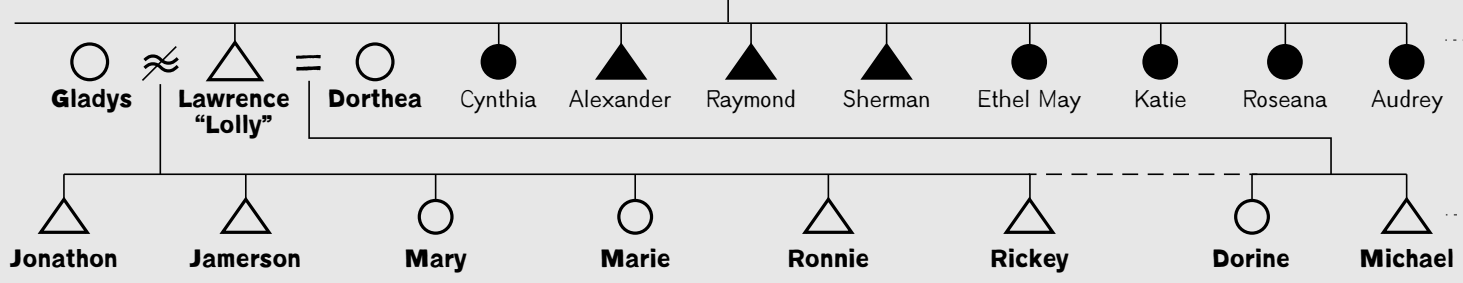




\section{Cynthia's Branch}

(Simplified)

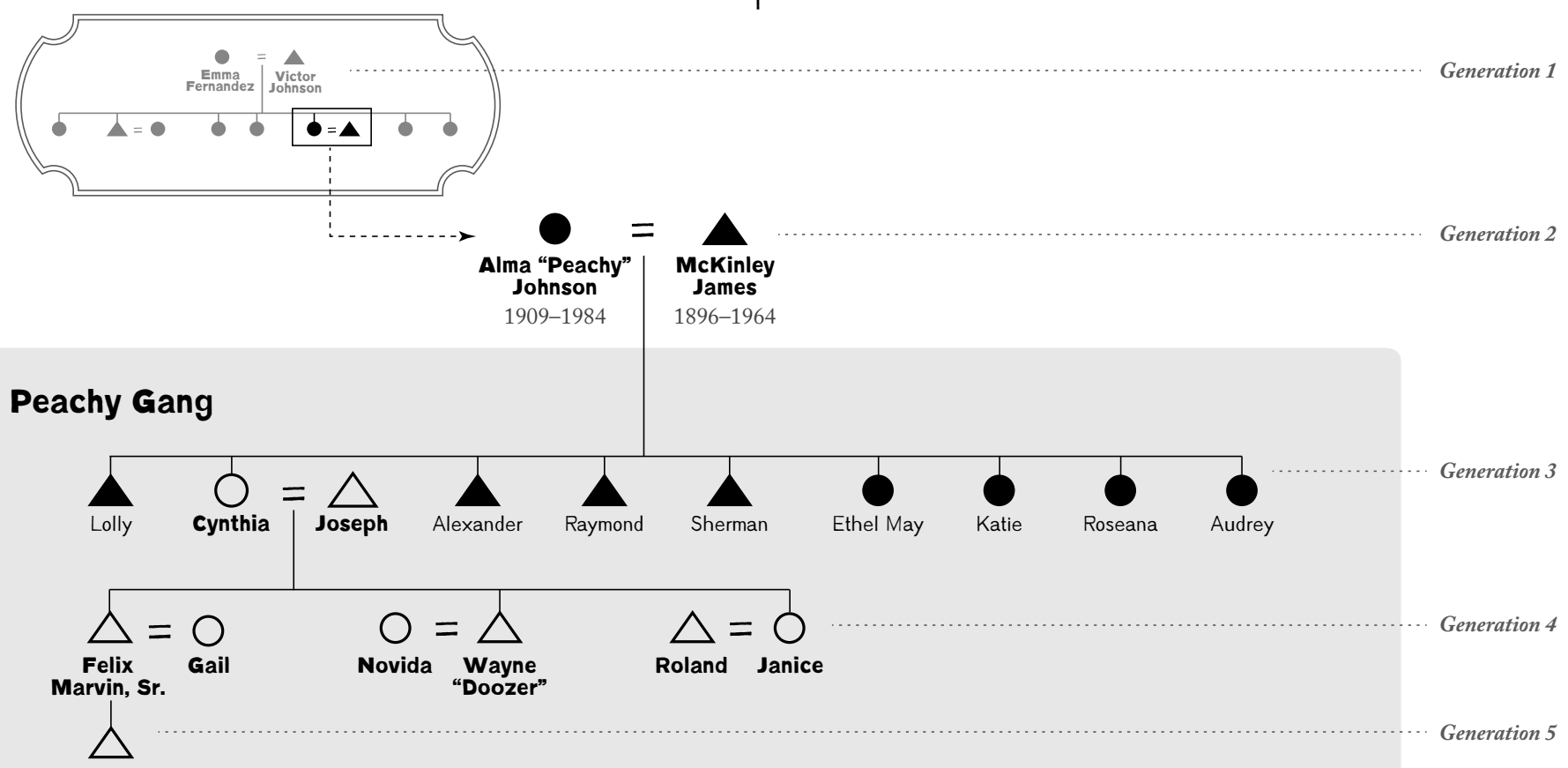

Felix Marvin, Jr. 


\section{Raymond's Branch}

(Simplified)

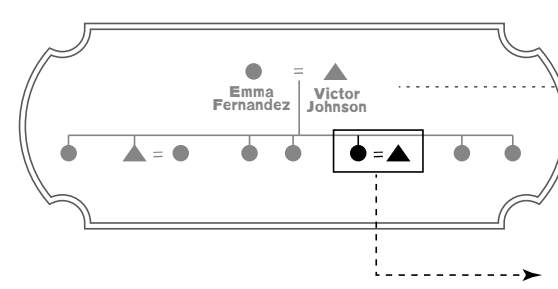

Generation 1

Alma "Peachy" McKinley

Johnson James

1909-1984

1896-1964

\section{Peachy Gang}

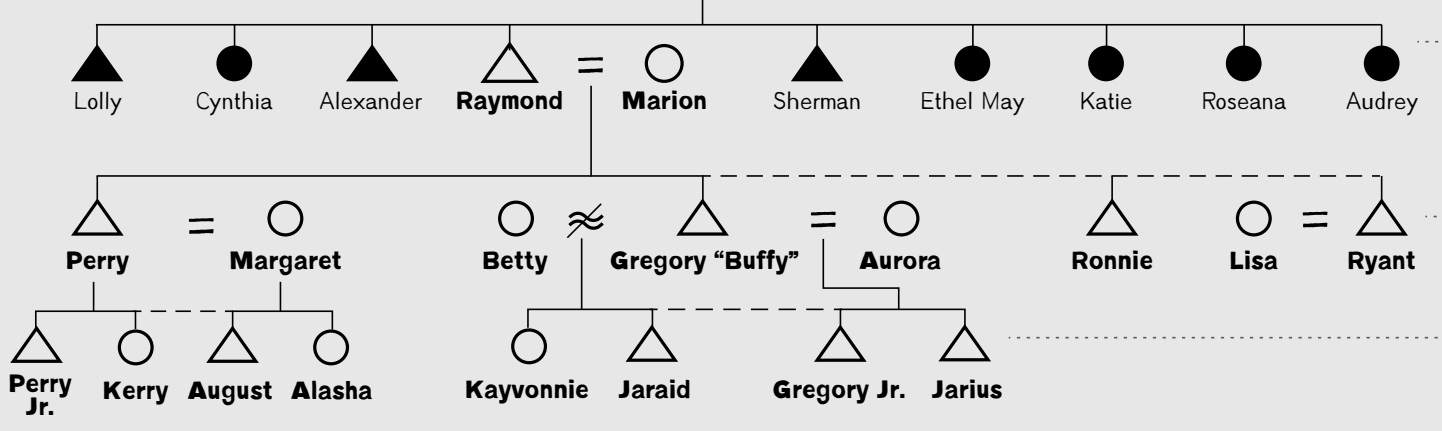




\section{Sherman's Branch}

(Simplified)

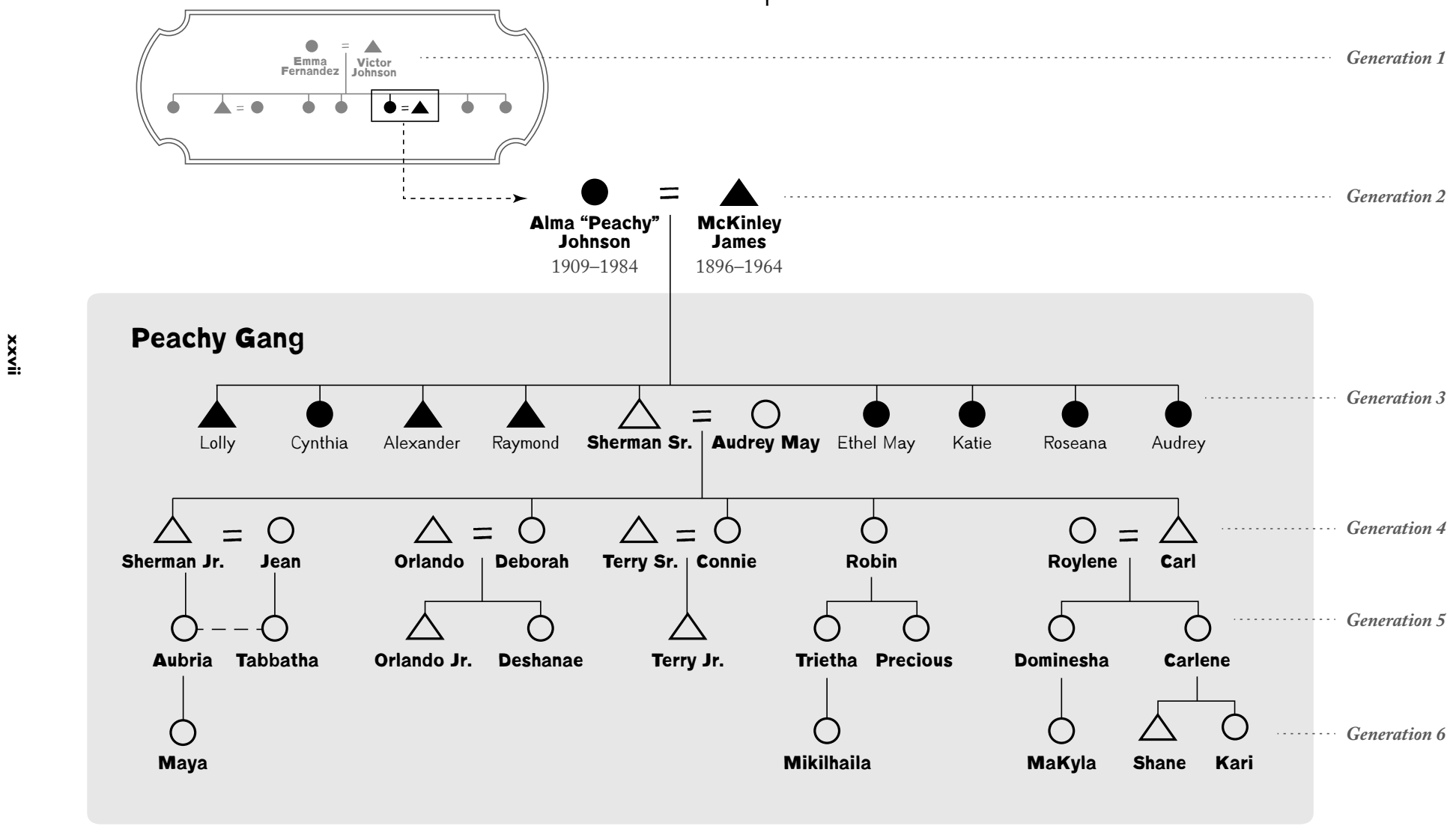




\section{Ethel May's Branch}

(Simplified)

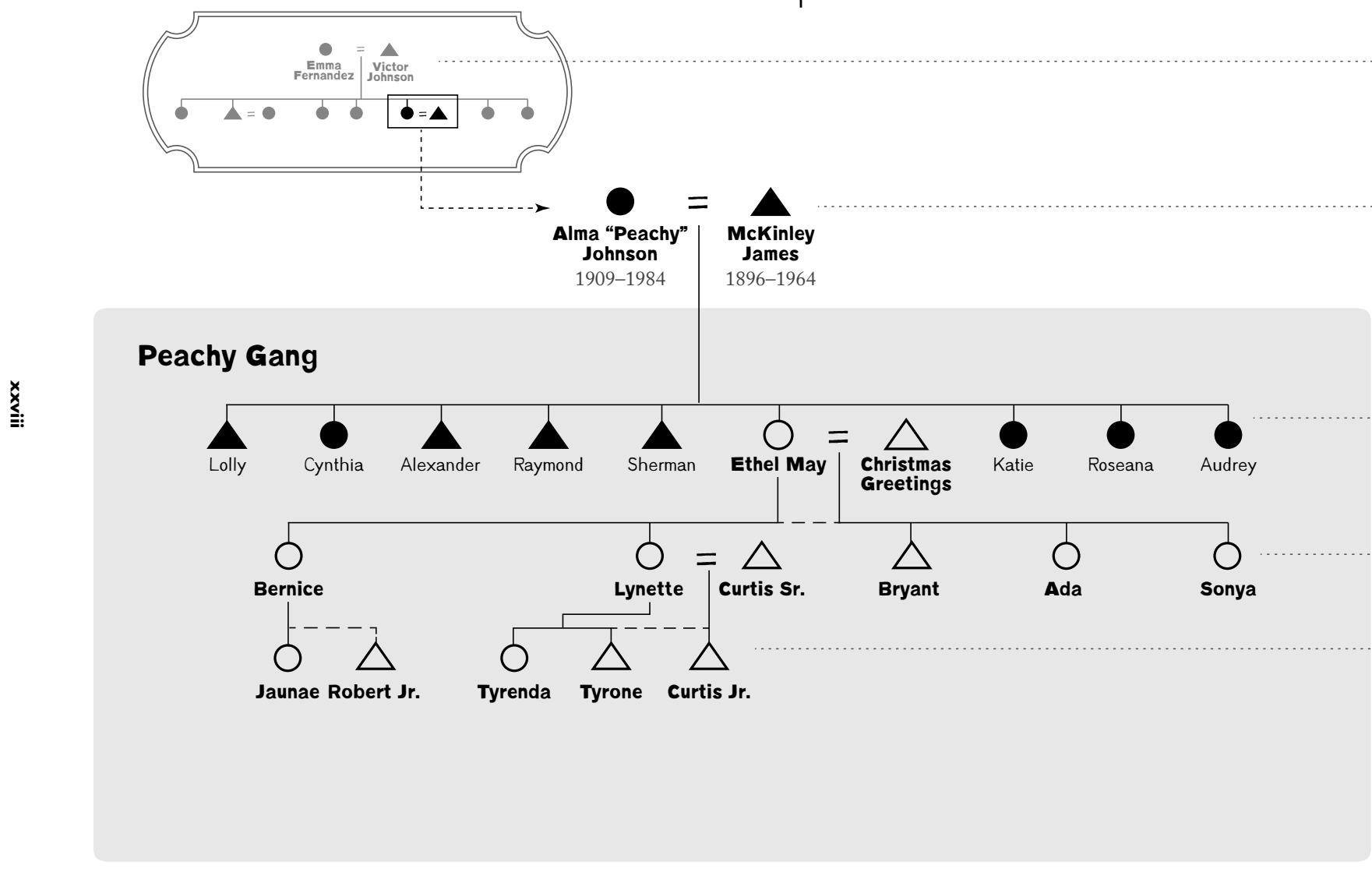

Generation 1

Generation 2 


\section{Katie's Branch}

(Simplified)

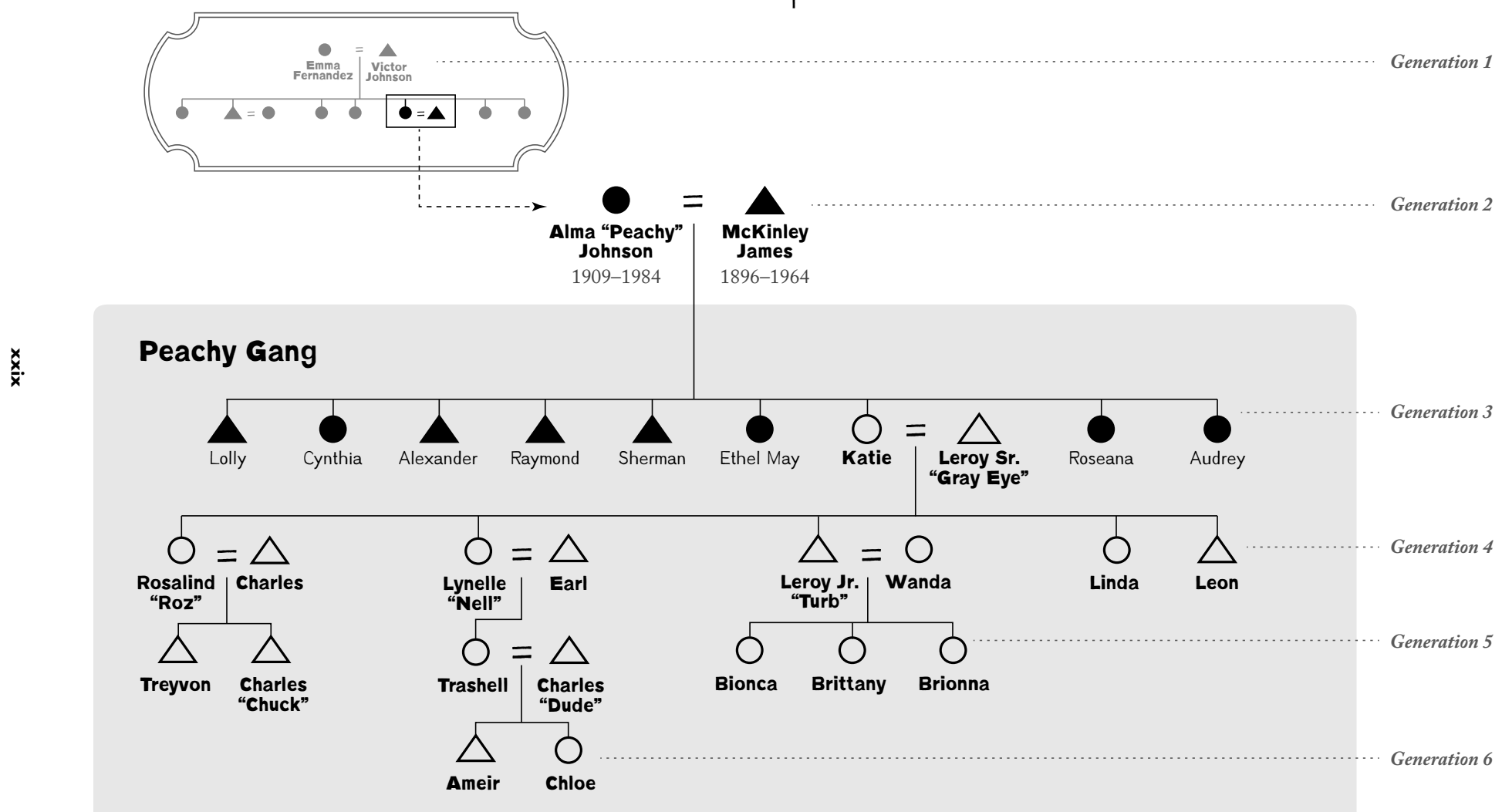




\section{Roseana's Branch}

(Simplified)

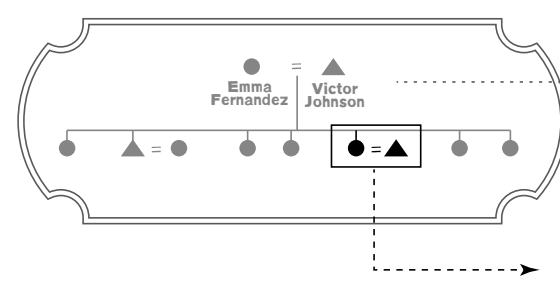
$\underset{\substack{\text { Alma "Peachy" } \\ \text { Johnson }}}{O}=\underbrace{}_{\substack{\text { Mckinley } \\ \text { James }}}$

1909-1984

1896-1964

Generation 1

Generation 2

Generation 3

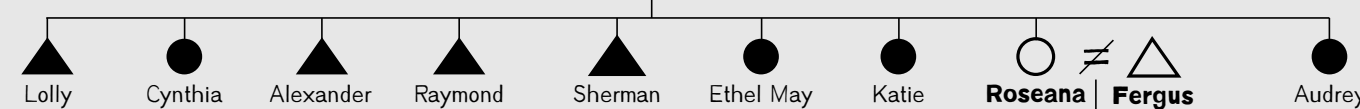

$\Delta=\stackrel{1}{0}$

Wilfred Jr. Desiree

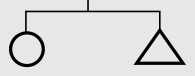

Dannielle Wilfred II

"Will"

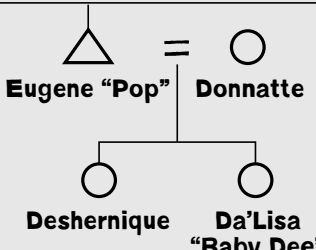

"Baby Dee"
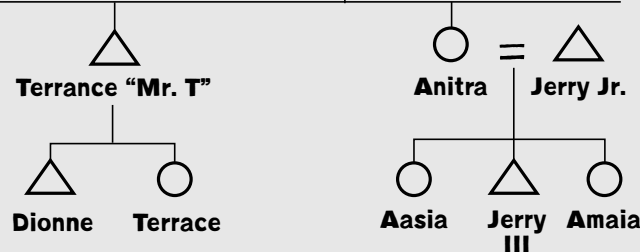


\section{Audrey's Branch}

(Simplified)

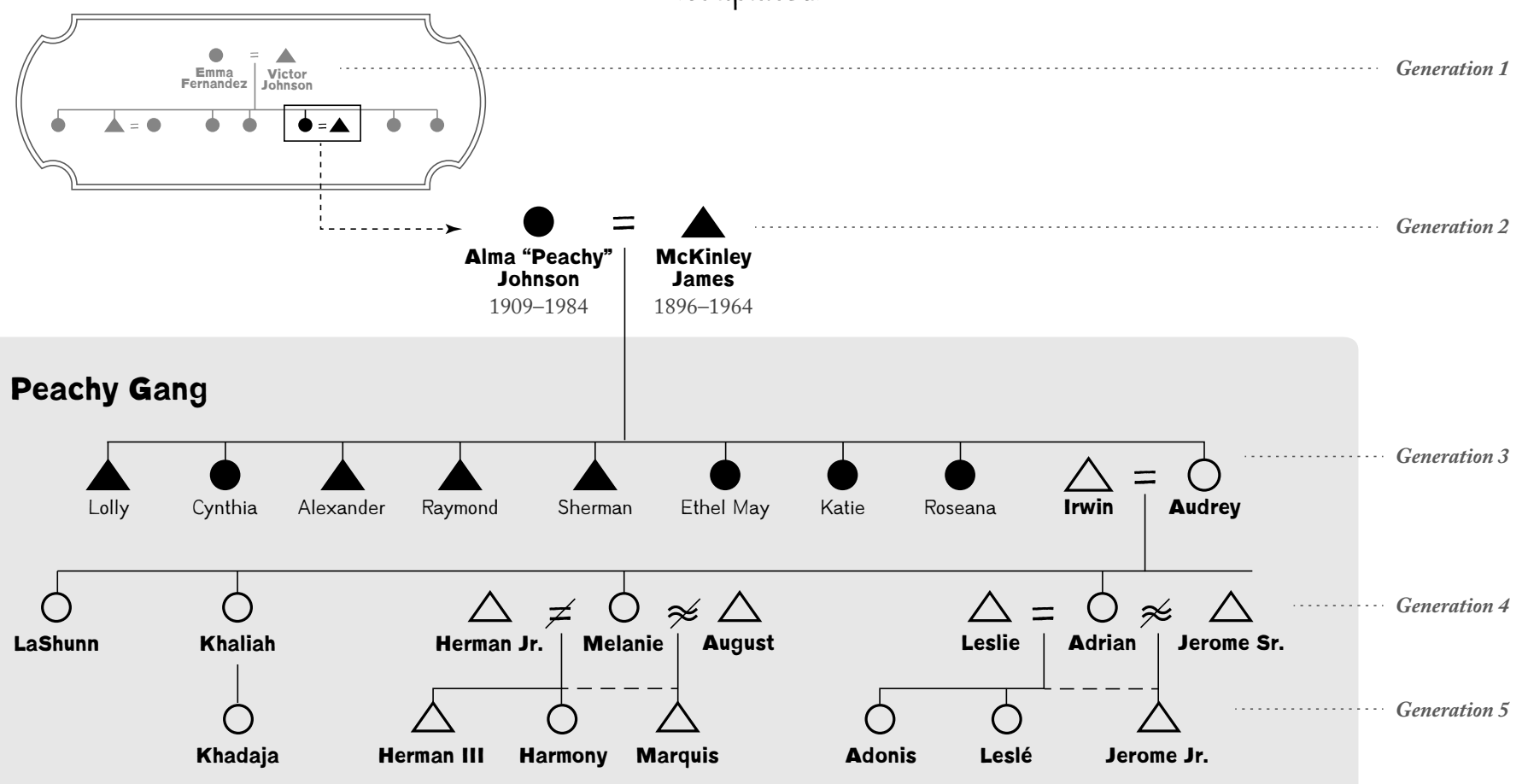




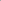

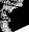
.

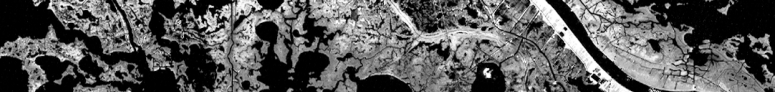

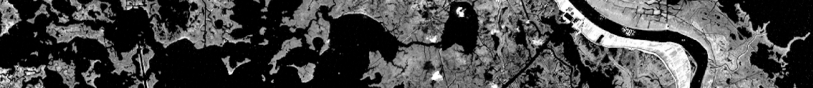


The brown pelican, state bird of Louisiana, makes its home on the bayou.

\section{The environment of lower St. Bernard Parish}
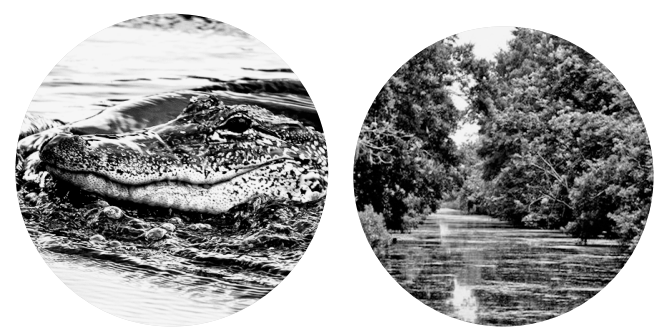

Gators glide through the bayous and swamps and sometimes end up as dinner.

Cypress swamps once dominated the landscape, providing refuge for slaves and trees for the timber industry.

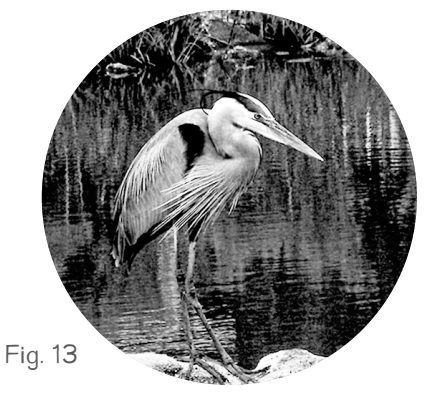

Great blue herons live off the

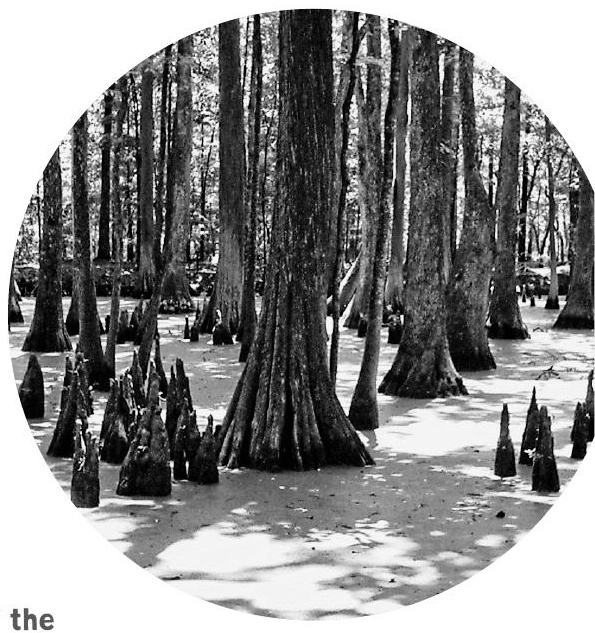
bounty of the bayou. 


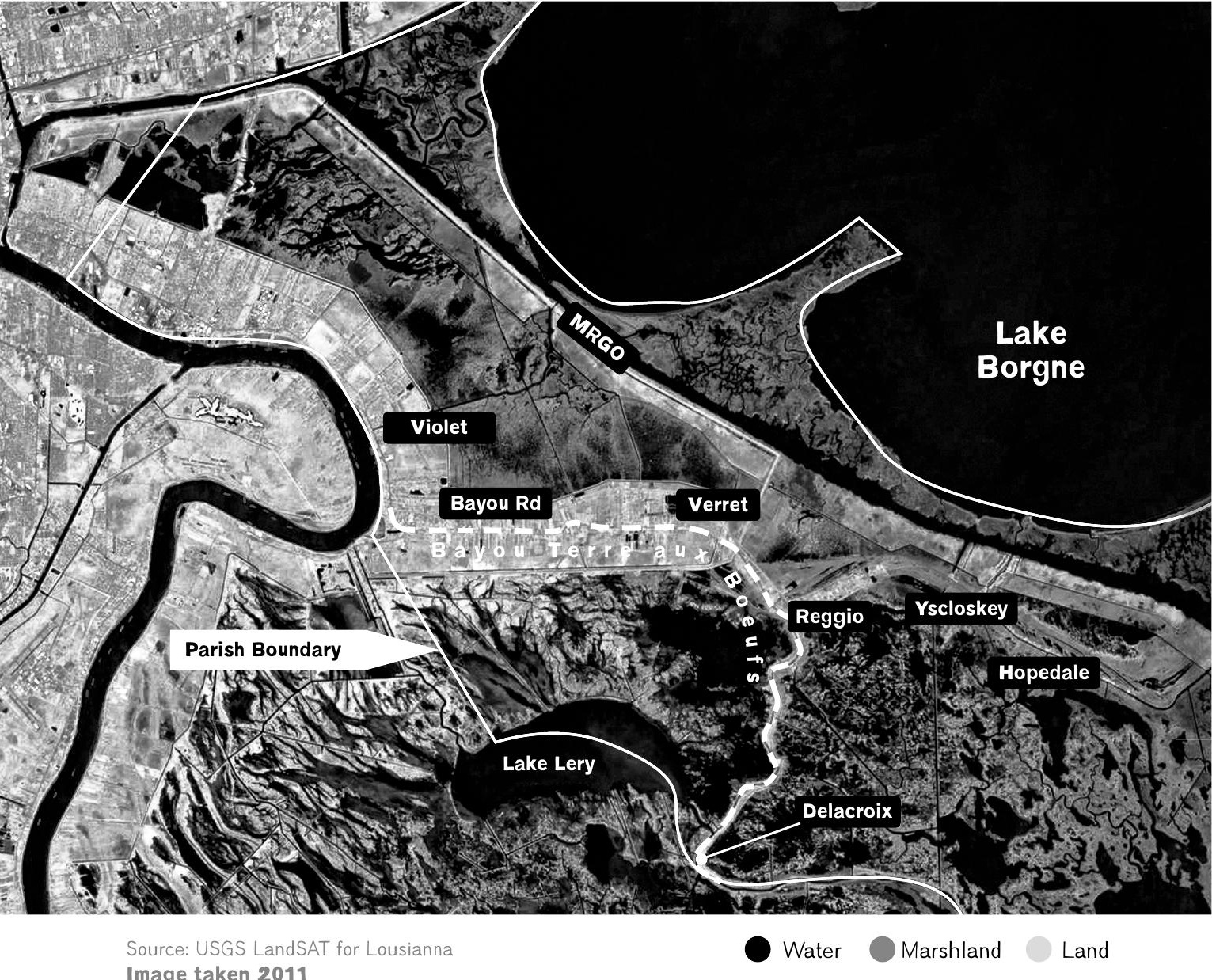

Image taken 2011

\section{The historic lower parish and disappearing land}

At the time the family rhizome took root on slave plantations near Verret on Bayou Terre aux Boeufs, a substantial hurricane buffer stood between them and the open waters of the Gulf.
Since 1930, Louisiana has lost 1,883 square miles of coastal lands, including protective wetlands and swamps.
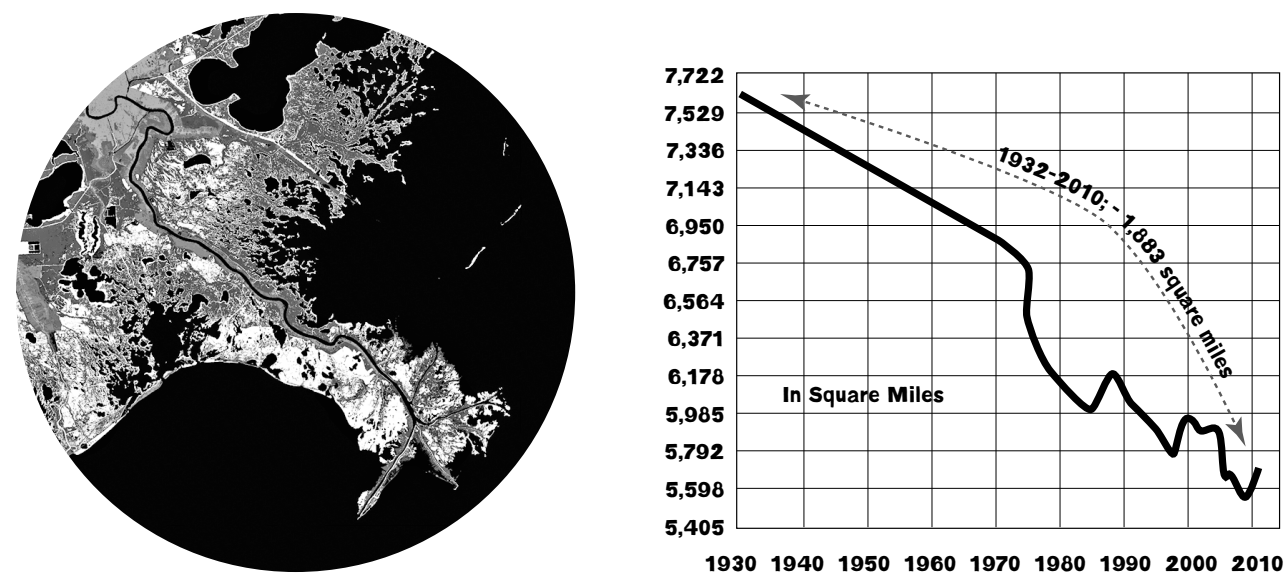

Fig. 14 White areas indicate land lost between 1932 and 2010 
THIS PAGE INTENTIONALLY LEFT BLANK 